\title{
回旋型人工骨頭置換術の短期予後調査について
}

\author{
熊本市民病院整形外科 \\ 堀川広通・広田耕三 \\ 園 莫 器・赤㥓幸 二
}

\section{Short Term Results of Prosthesis of the Rotation Type Femoral Head.}

By

\section{H. Horikawa K. Hirota H. Sonoda \\ and K. Akasaki}

Department of Orthopedic Surgery, Kumamoto Municipal Hospital

A follow-up study was performed on 30 hips in 29 cases.

The age at the time of operation ranged between 29 and 77 years, 61 year: in average.

The duration of follow-up was 12 months to 3 years and 11 months, 2 years and 3 months in average.

Satisfactory results were obtained in 26 hips ( $86 \%)$, especially fresh fracture of femur neck was excellent.

Proximal migration was found in 12 hips $(40 \%)$ and the result was poor than the cases which had no proximal migration.

Ectopic ossification was seemed in 9 hips and the result was good.

はじめに

H.D.P. 人工骨頭がその置換術後 $1 \sim 2$ 年以内に, かなりの高頻度に，磨耗による成績不良例を生じる事 は，すでに数回にわたり述べてきた. H.D.P. 骨頭の 磨耗は骨頭表面に著明に生じているが，回旋軸との間 には肉眼的に認められなかった事より, 回旋型の特色 を生かしながら磨耗を防ぐために，H.D.P. 骨頭ボー ルの表面を C.O.P. 鋼にて被覆した改良型を作成し, 昭和 49 年 6 月以降使用してきた（図 1). 現在までに 60 症例に使用したが, そのうち術後 1 年以上経過し 予後調査の可能であった 29 症例 30 関節について報告 する．なお，ステムの固定には全例に骨セメントを使 用している.

\section{症例}

術後 1 年以上 2 年未満 14 関節， 2 年以上 3 年未満 8 関節, 3 年以上 8 関節計 30 関節で, 術後経過期間

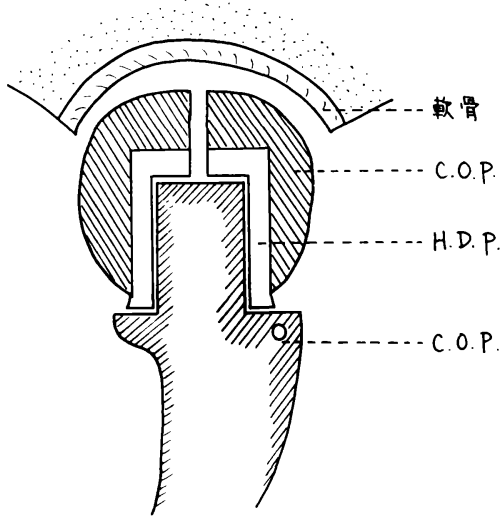

図 1 metal coveıed H.D.P. ball

(模式図)

は 1 年から 3 年 11 力月で平均 2 年 3 力月である. 性 別では男性 7 名 7 関節，女性 22 名 23 関節計 29 名 30 関節である. 手術時年令は最低 29 才, 最高 77 才で, 
表 1 症例

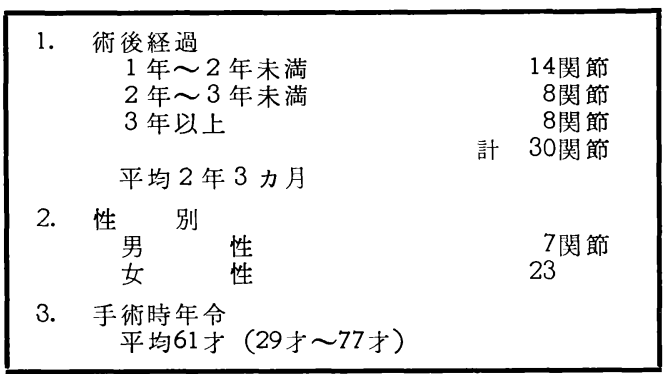

平均 61 才であった（表 1 ).

疾患別分類では, 大腿骨頸部骨折 21 関節で，その うち受傷より手術までの期間が 30 日未満を新鮮例, 30 日以上を陳旧例とすれば, 新鮮例 7 関節, 陳旧例 14 関節である. また変形性股関節症 3 関節, R.A. 2 関節, 無腐性壊死 2 関節, それに H.D.P. 人工骨頭の 磨耗によるもの 2 関節である（表 2 ).

表 2 疾患別分類

\begin{tabular}{|c|c|c|}
\hline $\begin{array}{l}\text { 大腿骨頸部骨折 } \\
\quad \text { 新 鮮 例 } \\
\text { 陳 旧例 } \\
\text { 変形性股関節症 } \\
\text { R A } \\
\text { 無腐性買死 } \\
\text { H D P 骨頭ボール磨耗 }\end{array}$ & $\begin{array}{r}7 \text { 関節 } \\
14 \text { 関節 }\end{array}$ & $\begin{array}{l}21 \text { 関節 } \\
3 \text { 関節 } \\
2 \text { 関節 } \\
2 \text { 関節 } \\
2 \text { 関節 }\end{array}$ \\
\hline
\end{tabular}

\section{結果}

はじめに疾患別に日整会変股症判定基準による総合 点数をみると, 大腿骨頸部骨折平均 89 点であり, そ のうち新鮮例 95 点, 陳旧例 85 点であった. また変股 症 78 点, R.A. 54 点, 無腐性壊死 87 点, H.D.P. 骨 頭磨耗例 75 点であった. 全体では平均 84 点である.

(表 3)

次に各項目別にみると

表 3 疾患別総合成績

\begin{tabular}{|c|c|c|}
\hline $\begin{array}{c}\text { 大腿骨頸部骨折 } \\
\text { 新 鮮 例 } \\
\text { 陳旧例 } \\
\text { 変形性股関節症 } \\
\mathrm{RA} \\
\text { 無腐性填死 } \\
\text { H D P 骨頭ボール磨耗 }\end{array}$ & $\begin{array}{l}95 \text { 点 } \\
85 \text { 点 }\end{array}$ & $\begin{array}{l}89 \text { 点 } \\
78 \text { 点 } \\
54 \text { 点 } \\
87 \text { 点 } \\
75 \text { 点 } \\
84 \text { 点 }\end{array}$ \\
\hline
\end{tabular}

疼痛：疼痛のないもの 22 関節 $73 \%$ \%, 軽度の疼痛 を訴えるもの 8 関節 $27 \%$ \%あり, 中等 度 以上の疼痛
表 4

監 床 成 紿

1. 疼痛

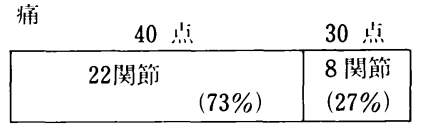

2. 可動性

\begin{tabular}{|c|c|c|}
\hline 20 点 & \multicolumn{1}{c}{$19 \sim 15$ 点 } & 14 点以下 \\
\hline $\begin{array}{c}14 \text { 関節 } \\
(47 \%)\end{array}$ & $\begin{array}{l}12 \text { 関節 } \\
(40 \%)\end{array}$ & $\begin{array}{l}4 \text { 関節 } \\
(13 \%)\end{array}$ \\
\hline
\end{tabular}

3. 少行能

\begin{tabular}{|c|c|c|c|}
\hline 20 点 & i in 15 & 10 点 & 5 点 \\
\hline $\begin{array}{l}8 \text { 関節 } \\
(27 \%)\end{array}$ & $\begin{array}{c}12 \text { 関節 } \\
(40 \%)\end{array}$ & $\begin{array}{l}7 \text { 関節 } \\
(23 \%)\end{array}$ & (10) \\
\hline
\end{tabular}

4. 目常生活能

\begin{tabular}{|c|c|c|c|}
\hline 20 㸃 & $19 \sim 15$ 点 & $14 \sim 10$ & 9 点以 \\
\hline 6 関節 & 15関節 & 3 & 6 関節 \\
\hline$(20 \%)$ & $(50 \%)$ & (10) & $(20 \%)$ \\
\hline
\end{tabular}

5. 総合成績

\begin{tabular}{|c|c|c|c|}
\hline $\begin{array}{c}\text { 優 } \\
90 \text { 点以上: }\end{array}$ & $\begin{array}{c}\text { 良 } \\
89 \sim 70 \text { 点 }\end{array}$ & $\begin{array}{c}\text { 可 } \\
69 \sim 60 \text { 点 }\end{array}$ & \\
\hline $\begin{array}{l}\text { 13関節 } \\
(43 \%)\end{array}$ & $\begin{array}{l}\text { 13関節 } \\
(43 \%)\end{array}$ & & 2 \\
\hline
\end{tabular}

を訴えるあのはいなかった

可動性：平均 18 点であり， 20 点群は 14 関節 $47 \%$ であった. また届曲についてみると， 30 関節中 25 関 節が 90 度以上の屈曲可能であった.

歩行能: 20 点群は 8 関節 $27 \%, 15$ 点群 12 関節 40 $\%, 10$ 点群 7 関節 $23 \%, 5$ 点群 3 関節 $10 \%$ で平均 14 点であった. 5 点群 3 関節のうち 1 例 2 関節は 20 年 来の R.A. 患者で, 他の関節の拘 縮 強直があり, 術 前はほとんど寝たきりの状態であったが, 術後は松葉 杖使用するも疼痛はなく屋内活動が出来, 患者は非常 に満足している.

日常生活動作能：20 点を示すものは 6 関節 $20 \%$ と 少ないが, 15 点以上を示すむのは 21 関節 $70 \%$ であ る.

総合成績：90 点以上を優， 89 点から 70 点を良， 69 点から 60 点を可, 60 点未満を不可とすると, 優 13 関 節 $43 \%$ ，良 13 関節 $43 \%$ で，26関節 $86 \%$ はほぼ満 足 できる結果が得られたものと考える. 不可の 2 関節は 前述の R.A. 患者であり, むしろ他の関節に問題が あるためである.（表 4)

Proximal migration: 12 関節に認められた. こ れを疾患別にみると, 大腿骨頸部骨折陳旧例14関節中 6 関節に，変股症 3 関節中 2 関節に，R.A. 2 関節中 
表 5 Proximal Migration

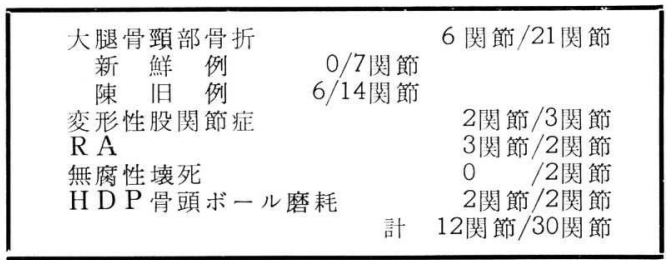

2 関節，H.D.P. 骨頭磨耗 2 関節中 2 関節に認められ たが，頸部骨折新鮮例，無腐性骨頭壊死例には認めら れなかった。（表 5)

Proximal migration の有無之臨床成績との関係 をみると, migrationの認められるものは平均 74 点, 認められない屯の平均 91 点で, migration の認 められるものの方が点数が低かった（表 6 ).

脚延長と Proximal migration:

表 6 Proximal Migration と臨床成績

\begin{tabular}{|cc|c|c|c|c|c|}
\hline & 疼痛 & 可動性 & 歩行能 & $\begin{array}{c}\text { 日常 } \\
\text { 生活 }\end{array}$ & 総合 \\
\hline 有り & 12関節 & 34 & 18 & 10 & 12 & 74 \\
無乙 & 18関節 & 39 & 19 & 17 & 16 & 91 \\
\hline
\end{tabular}

表 7 脚延長と Proximal Migration

\begin{tabular}{|c|c|}
\hline $\begin{array}{l}\text { 脚 }{ }^{\text {延 }}{ }^{\text {長 }} \\
\text { 有り }{ }^{18} \text { 関節 } \\
\text { 無し } \\
12 \text { 関節 }\end{array}$ & $\begin{array}{r}\text { Migration 有り } \\
10 \text { 関節 }(56 \%) \\
2 \text { 関節 }(17 \%)\end{array}$ \\
\hline
\end{tabular}

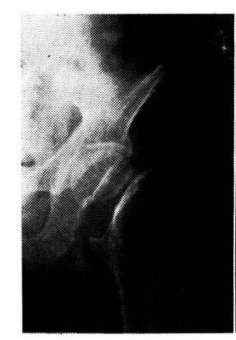

術 前

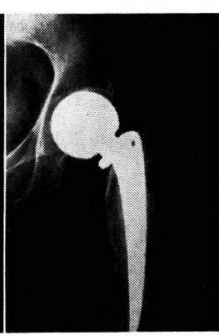

術直後

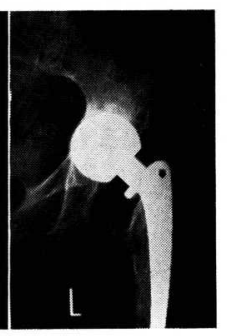

術後 3 年 2 力月
図 2 大腿骨頸部骨折陳旧例。脚延長と Proximal migration.

大腿骨頸部骨折新鮮例については, 手術直後の X 線 像により小転子の高さを計測し，健側と患側とを比較 し，他の疾患では，術前術後のX線像により小転子の 高さを計測し，患側同志を比較した. これは，頸部骨 折陳旧例, 変股症等では, 長期にわたり脚短縮の状態 で生活していると考えたためである. 脚延長の有無と proximal migration との関係をみると, 脚 延長の あるもの 18 関節中 10 関節 $(56 \%)$ proximal migration がみられたが，脚延長のないもの 12 関節 中では 2 関節(17\%)に migration がみられたのみで， この 2 関節は共に R.A. 患者であった.（表 7 )（図 2 )

透明層は 4 関節に認められた。そのうち 3 関節が大 転子側に，1関節が小転子側にみられたがすべて部分 的に出現していた.

異所性化骨は 9 関節 $30 \%$ にみれたが，その臨床 成績は，化骨があるもの 86 点, ない屯の 83 点であ り，異所性化骨による臨床成績の低下は認められなか った.

Distal migration については，全例に骨セメント を使用しているためか認められなかった.

\section{ま と め}

術後 1 年以上経過した 29 症例 30 関節について，日 整会判定基準による予後調査を行なった.

(1) 総合成績では，26 関節 $86 \%$ ほぼ満足すべき 結果を得た. 各項目別では疼痛および可動性に良好な 結果を得たが，歩行能および日常生活動作能では，前 二者と比較してその成績は少っていた。

(2) 疾患別では大腿骨頸部骨折新鮮例が平均 95 点 と満足す心゙き結果を得た.

(3) Proximal migration は 12 関節 $(40 \%)$ にみ られ，その臨床成績は平均 74 点であり, migrat'on のないものに比較してその成績は劣っていた.

(4) 術後脚延長を示した 12 関節中 10 関節に proximal migrationを認めた. またステムの固定に骨 セメントを使用しているため distal migration を認 めるものはなく, 脚延長が Proximal migration に より代償されているものと思われる. 以上より人工骨 頭置換術は高令者の大腿骨頸部骨折新鮮例には良い適 応と思われるが，他の疾患への適応は慎重に決める必 要があり，また術後脚延長をおこさないように術中の 頸部の長さの決定には注意が必要である.

\section{文献}

1) 明石武彦：中部整災誌，21：313-329，1978.

2) 柏木大治: 臨整外, 8:368-378, 1973.

3）木下 勇: 臨整外, 13: 269-274, 1978.

4) 広田耕三：西日本整災誌，25：313，1976.

5）增田武志：臨整外，13：31-37, 1978

6）高須咀良一：西日本整災誌，23：486, 1974.

7）矢野希人：西日本整炎誌，24：76, 1975. 